\title{
The Relationship of Indonesian Language Learning with the Environment
}

\author{
By : Rani Rahayu \\ ranirahayu@gmail.com
}

The environment is defined as all objects, conditions, circumstances and influences that exist in the room that we live in and affect living things, including human life (Emil Salim 1976). Problems regarding the environment are not something new. Environmental problems are closely related to the pattern of human life as well as the development of human language. Apart from our country, Indonesia, other countries also have environmental problems. This environmental problem occurs as a result of human careless actions towards nature in order to fulfill and improve their quality of life (Huang and Kawata, and Wihardjo et al, in Ramadhan et al, 2019).

One of the main causes of environmental pollution is not only individuals, but also the industrial sector that releases waste from industry as well as industrial factory smoke pollution which affects environmental conditions, natural resources, and surrounding human resources. The environment that has been polluted will directly threaten the comfort and increase the vulnerability of every citizen's life. For this reason, the government should be more assertive in dealing with environmental problems and pay more attention to industrial sectors which are one of the causes of environmental pollution. Environmental problems are increasing and complex, various environmental management programs both at the central and regional levels are designed to address various developments in environmental problems.

These cases of environmental pollution are due to carelessness or negligence of industrial companies including the textile industry to dispose of their waste carelessly in places such as rivers which are still used by the community, such as for bathing, washing and other needs. And also because of dishonesty, industrial companies dispose of waste that does not comply with the quality standards or the maximum limit of liquid waste that is allowed to be discharged into the natural environment. In fact, every activity carried out by a company, especially in terms of disposing of industrial waste, must have an environmental permit.

The decreasing quality of the environment has threatened the continuity of the lives of humans and other living creatures, so it is necessary to protect and manage the environment 
seriously and consistently by all stakeholders. Environmental problems faced by the community, especially in big cities, have become daily problems. This gives the impression that the community no longer cares about these environmental problems. This indifference is caused by various reasons, one of which is a lack of education. Therefore, it is necessary to have education about the environment which is expected to increase the awareness of the education community in particular and in turn the community in general regarding the environmental problems faced, increasing the active participation of the community in overcoming environmental problems.

To overcome this, teachers play an important role in teaching environmental education and fostering students' awareness of the environment. According to Buldur and Omeroglu (in Ramadhan et al, 2019), environmental education is important to increase students' attitudes and awareness of the environment. To overcome the problem of environmental damage, a serious action is needed to prevent environmental damage from getting worse. According to Nazarenko and Bergman (in Ramadhan et al, 2019).

Learning Environmental Education which has now been and is increasingly being implemented in schools is not employing students as workers in the school environment, but building a spirit of loving the environment, with the hope that the next generation will become a generation with environmental culture and become a habit for all school members. For this purpose, the school and all stakeholders and environmentalists should make a holistic concentration to education consumers about the role of the environment in the sustainability of life on earth, threats to life and solutions to save life on earth, and explain the portion of school attention in this is the student of the surrounding environmental ecosystem.

According to Jacobs G. M and Cates K (in Ramadan et al, 2019), the purpose of education environment is to make students participate in protecting the environment is to make students participate in protecting the environment. The role of the teacher is very necessary to teach the importance of protecting the environment and implementing it in everyday life. The role of the teacher is not only teaching, but also as a motivator in the learning environment for students, so that students are motivated to be able to apply it in everyday life. This can be done by including material on the importance of the environment in Indonesian language learning. 
From the data generated regarding language learning and teaching should be environmentally based, $32.5 \%$ strongly agree, 65\% agree, and 2.5\% disagree. In language learning with the theme of the environment is one indication of being able to form intelligence of the heart, mind, and hands where the three competencies are related to one another, $42.5 \%$ strongly agree, $55 \%$ agree, and $2.5 \%$ disagree. Language learning that is more "contextual" with nature should be the main choice again, 30\% strongly agree, $52.5 \%$ agree, and $17.5 \%$ disagree. As a teacher or prospective language teacher, it is time for language learning orientation, both national and local, to use texts with environmental themes, $30 \%$ strongly agree, $57.5 \%$ agree, and $12.5 \%$ disagree. The use of learning themes about nature in its division needs to be done for the sake of enrichment of reading materials and language learning materials, $32.5 \%$ of respondents strongly agree, and $67.5 \%$ of respondents agree. Having a strong stand in the natural environment as a living space for language learning is very important for students, 35\% of respondents strongly agree, $62.5 \%$ agree, and $2.5 \%$ of respondents disagree. Educational institutions have an important role in the process of cultivating environmental insight education to students, and educators are always connecting the process of environmentally based positive values to students, $47.5 \%$ of respondents strongly agree, $50 \%$ of respondents agree, and $2.5 \%$ respondon expressed disagreement. Environmental insight education can be integrated into Indonesian language subjects to provide comprehensive knowledge and skills in protecting the environment, $22.5 \%$ of respondents strongly agree, $72.5 \%$ of respondents agree, and $5 \%$ of respondents disagree. Environmental materials make it easier for students to understand Indonesian language material well, add to students 'insights, and can build students' ecological intelligence, $37.5 \%$ of respondents strongly agree, and $62.5 \%$ agree. Environmental material is material that is very closely related to everyday life, making it easier for teachers to find relevant examples and making students better understand the material provided, $47.5 \%$ of respondents strongly agree, $50 \%$ of respondents agree, $2.5 \%$ respondents disagree.

From the results of filling out the questionnaire that the author has done, it can be concluded that in general students agree and even strongly agree with environmental material in Indonesian language learning. Because by using the environmental theme in learning Indonesian, it can introduce students to the environment, so it is hoped that it can increase students' sense of care for their environment, especially for the cleanliness of their environment. 


\section{Bibliography}

Jacobs G M and Cates K.(2012). Global education in second language and teaching International Journal of Physical and Social Sciences 2 1-22

Kollmuss A and Agyeman J. (2002). Mind the gap: Why do people act enviconmentally and what are the barriers to pro-environmental behaviour Environmental Education Research $239-60$

Lai C S. (2018) A study of fifth graders' environmental learning outcomes in Taip International Journal of Research in Education and Science 4 252-61

Mitsuki I. (2017) Beyond the limitations of environmental education in Japan Educational Studies in Japan: International Yearbook 3-14

Nieblas-Ortiz E C, Acrcos-Vega J L and Sevilla-Garcia J J 2017 The construction of an environmental management model based on sustainability indicators on a higher education institution in Mexico Higher Education Studies 7 15-22

Mitsuki, I. (2017). Beyond the limitations of environmental education in Japan Educational Studies in Japan: International Yearbook Number 11 pp 3-14

Bergman, B.G. (2016). Assessing impacts of locally designed environmental education projects on students' environmental attitudes, awareness, and intention to act Environmental Education Reseach 22(4) 480- 503

Buldur, A. and Ömeroglu, E. (2018). An examination of the relationship between pre-school children's and their teacher' attitute and awareness towards the environment Journal of Education and Learning 7(2) 221-9

Lai, C.S.(2018). A study of fifth graders' environmental learning outcomes in Taipei International Journal of Research in Education and Science 4(1) 252-61

Ramadhan, S., Sukma, E., \& Indriyani, V. (2019). Environmental education and disaster mitigation through language learning. IOP Conference Series: Earth and Environmental Science, 314.

Nazarenko, A.V. and Kolesnik, A.I. (2018). Raising environmental awareness of future teachers International Journal of Instruction 11(3) 63-76 